\begin{tabular}{c} 
JURNAI RIS'II \\
IAll \\
$\begin{array}{l}\text { (Rekayasa Sistem dan Teknologi Informasi) } \\
\text { Vol.5 No.1 (2021) } 31-38\end{array}$ \\
\hline
\end{tabular}

\title{
Presensi Kelas Berbasis Pola Wajah, Senyum dan Wi-Fi Terdekat dengan Deep Learning
}

\author{
Miftakhurrokhmat $^{1}$, Rian Adam Rajagede ${ }^{2}$, Ridho Rahmadi ${ }^{3}$ \\ 123 Magister Informatika, Fakultas Teknologi Industri, Universitas Islam Indonesia \\ 118917214@students.uii.ac.id, ${ }^{2}$ rian.adam@uii.ac.id, ${ }^{3}$ ridho.rahmadi@uii.ac.id*
}

\begin{abstract}
Students' attendance in class is often mandatory in education and becomes a benchmark for assessing students. Sometimes there are still fraudulent practices by students to achieve minimum attendance. From the administrative perspective, a paper-based presence system is potentially wasteful and extends the administrative stage because it requires manual recapitulation. This study aims to design a class attendance application based on facial pattern recognition, smile, and closest Wi-Fi. The method used in this research is a deep learning approach with CNN based architecture, FaceNet, to recognize faces. In addition to facial images, the system will also validate the attendance with location and time data. Location data is obtained from matching SSID from the database, and time data is taken when the user sends attendance data through API. This attendance system consists of three applications: web, mobile, and services installed on a mini-computer, which are integrated to sending attendance data to the academic system automatically. As confirmation, students are required to smile selfies to strengthen the validity of their presence. The testing model's accuracy results are 92.6\%, while for live testing accuracy the model obtained $66.7 \%$.
\end{abstract}

Keywords: presence, smiling, face recognition, convolutional neural network, deep learning

\begin{abstract}
Abstrak
Kehadiran mahasiswa dalam suatu pembelajaran di kelas seringkali menjadi syarat wajib dalam dunia pendidikan, dan menjadi tolak ukur dalam menilai mahasiswa. Terkadang masih dijumpai praktik curang oleh mahasiswa dalam presensi agar mencapai kehadiran minimal. Dari sisi administrasi, presensi berbasis kertas berpotensi pemborosan dan juga memperpanjang tahapan administrasi karena membutuhkan rekapitulasi manual. Penelitian ini bertujuan untuk merancang bangun aplikasi presensi kelas berbasis pengenalan pola wajah, senyum, dan WiFi terdekat. Metode yang digunakan dalam penelitian ini adalah pendekatan Deep Learning dengan arsitektur $C N N$ FaceNet untuk mengenali wajah. Selain gambar wajah, sistem juga akan memvalidasi presensi dengan kesesuaian lokasi dan waktu. Data lokasi diperoleh dari pencocokan SSID dengan database, dan data waktu diambil saat mahasiswa mengirimkan data kehadiran melalui API. Sistem presensi ini terdiri dari tiga aplikasi yaitu web, mobile, dan service yang dipasang di komputer mini, yang saling terintegrasi untuk mengirimkan data presensi ke sistem akademik secara otomatis. Sebagai konfirmasi, siswa diwajibkan selfie tersenyum untuk memperkuat validitas kehadiran. Sistem terintegrasi ini masih dalam bentuk purwarupa. Hasil akurasi dari testing model sebesar $92,6 \%$ sedangkan untuk testing live akurasi sebesar $66,7 \%$. Nilai testing live lebih kecil dan cukup jauh dari testing model dapat diartikan hasil training model terlalu overfitting.
\end{abstract}

Kata kunci: presensi, senyum, pengenalan wajah, convolutional neural network, deep learning

\section{Pendahuluan}

Hingga saat ini, terdapat berbagai cara yang dilakukan untuk kegiatan presensi, baik di lingkungan pendidikan, pemerintahan, atau bidang lainnya. Sebagian menggunakan teknologi terkini seperti pengenal sidik jari (finger print) [1], namun tidak sedikit pula institusi

Diterima Redaksi : 17-10-2021 | Selesai Revisi : 28-01-2021 | Diterbitkan Online : 13-02-2021 
yang masih menggunakan sistem manual seperti tanda Pada penelitian sebelumnya [11], dikembangkan sebuah tangan pada buku dan kemudian direkapitulasi untuk sistem presensi mahasiswa berdasarkan pengenalan memperoleh laporan akhir dari kehadiran. Proses wajah menggunakan webcam dan mini PC dengan presensi secara manual memiliki banyak kekurangan metode Haar Cascade untuk pendeteksian wajah, Local seperti pemborosan kertas, rekapitulasi yang memakan Binary Pattern dan K-Nearest Neighbor untuk waktu, sulit untuk diintegrasikan dengan sistem lain, dan pengenalan wajah. Nilai akurasi pengenalan wajah yang rentan terhadap pemalsuan.

Sistem presensi yang berbasis sidik jari, seringkali dibangun pada platform yang hardcoded (tidak mengizinkan komunikasi dengan sistem atau piranti lain) sehingga menyulitkan ketika harus diintegrasikan dengan sistem utama pada sebuah institusi. Sistem presensi seperti ini juga rentan terhadap peretasan atau pemalsuan sidik jari $[2,3]$. Alternatif lain seperti presensi menggunakan kartu memiliki isu yang sama: dibangun pada sebuah sistem yang tidak mudah untuk diintegrasikan dengan sistem utama seperti sistem informasi akademik. Belum lagi penggunaan kartu sangatlah rentan terhadap pemalsuan karena kartu bisa dengan mudah dipindahtangankan. Lebih jauh lagi, dibutuhkan biaya yang relatif tidak sedikit untuk mencetak kartu [4,5]. Dalam hal ini, dibutuhkan sebuah solusi untuk presensi yang menjawab isu-isu permasalahan diatas.

Beberapa penelitian sebelumnya [6,7], memberikan solusi presensi dengan menghadirkan sistem pengenalan pola wajah berbasis mobile. Alternatif ini cukup efektif untuk diintegrasikan dengan sistem utama pada sebuah institusi, di samping penghematan penyediaan alat presensi. Namun, beberapa faktor [8] turut berpengaruh dalam keakuratan pengenalan wajah. Sehingga perlu dilakukan pengembangan lebih lanjut lagi untuk sebuah aplikasi pengenalan wajah seperti memanfaatkan CCTV dan menjadikannya berbasis mobile.

didapatkan sebesar $78,125 \%$ dengan $k=2$. Selanjutnya pada penelitian yang lain [12], digunakan metode Haar Cascade untuk pendeteksian wajah pada video dan Deep Learning untuk identifikasi. Hasil ujicoba dari penelitian tersebut mendapatkan tingkat akurasi 99,6\% dengan syarat komposisi warna dan tingkat cahaya video sama dengan data training. Peneliti akan menggunakan metode DLib untuk pendeteksian wajah, dan metode Deep Learning dengan arsitektur berbeda yaitu FaceNet dengan harapan mampu memperbaiki kelemahan yang berkaitan dengan komposisi warna dan tingkat cahaya. Selain itu, penelitian ini akan mengintegrasikan beberapa komponen yaitu CCTV untuk menangkap gambar, mini komputer untuk memproses pengenalan wajah, dan smartphone untuk konfirmasi.

Penelitian ini bertujuan untuk merancang bangun sebuah sistem untuk melakukan presensi berbasis pola wajah dan ekspresi senyum, lokasi dan waktu yang tepat sesuai jadwal. Sebuah contoh untuk mengilustrasikan cara bagaimana aplikasi ini bekerja adalah sebagai berikut: seorang mahasiswa yang masuk kedalam ruang kelas akan mendapatkan notifikasi di smartphone, untuk mengkonfirmasi bahwa mahasiswa tersebut masuk ke kelas yang telah sesuai. Konfirmasi dapat dilakukan dengan tersenyum ke arah smartphone atau dengan menekan tombol check-in. Kemudian ketika kelas telah berakhir dan mahasiswa keluar, berdasarkan data posisi mahasiswa di luar kelas yang didapat dari access point (Wi-Fi) di ruangan tersebut, mahasiswa tersebut akan Deteksi wajah dapat dipandang sebagai sebuah metode mendapatkan notifikasi untuk check-out. Proses checkklasifikasi pola dimana inputnya adalah citra dan output- out dapat dilakukan dengan tersenyum ke arah nya adalah label dari citra tersebut. Pendeteksian wajah smartphone, yang akan dilanjutkan dengan sebuah (face detection) adalah salah satu tahap awal yang sangat notifikasi untuk menginformasikan jika yang penting sebelum dilakukan proses pengenalan wajah bersangkutan telah presensi di kelas tersebut. Data (face recognition). Bidang-bidang penelitian yang presensi tersebut akan secara otomatis disimpan ke berkaitan dengan pemrosesan wajah (face processing) dalam sistem informasi akademik.

diantaranya: pengenalan wajah (face recognition), autentikasi wajah (face authentication), lokalisasi wajah (face localization), penjejakan wajah (face tracking), dan pengenalan ekspresi wajah (facial expression recognition) [9].

\section{Metode Penelitian}

Bagian ini berisi diagram alir langkah penelitian secara umum pada sistem presensi kelas berbasis pola wajah tersenyum dan Wi-Fi terdekat ditunjukkan pada Gambar 1.

Face Recognition (FR) adalah teknik biometrik yang sangat baik untuk otentikasi identitas. Teknologi FR Adapun secara garis besar urutan penelitian adalah dapat diterapkan untuk pencatatan kehadiran secara sebagai berikut: Studi Pustaka dengan melakukan otomatis di lingkungan akademis. Terdapat beberapa pencarian jurnal dan artikel yang memiliki kemiripan keuntungan menggunakan sistem kamera, seperti dengan penelitian terkait dan selanjutnya melakukan menghemat waktu dan tenaga, memberikan bukti kuat evaluasi terhadap metodologi yang dilakukan. Analisis untuk penjaminan mutu dan tugas manajemen sumber perancangan meliputi analisis kebutuhan, yaitu daya manusia, menghindari perantaraan penyakit software, hardware, dan teknologi yang digunakan menular [10]. untuk integrasi baik sisi database, mobile, web, IP CCTV maupun network. Pengumpulan data dilakukan 
secara kolektif, mahasiswa dapat mengirimkan data Beberapa perancangan yang dilakukan seperti berupa foto maupun video. Tahap selanjutnya adalah perancangan basis data berupa tabel-tabel dan use case pemilihan arsitektur yang akan digunakan, dalam hal ini diagram. Gambar 2 menunjukkan contoh tabel utama FaceNet yang merupakan salah satu arsitektur deep untuk presensi dan notifikasi.

learning. Training dan testing dataset dipersiapkan dari tahapan sebelumnya yaitu pengumpulan foto. Implementasi model hasil training dataset diterapkan menggunakan script Python sebagai background service pada mini komputer. Aplikasi web untuk dosen dibangun diatas framework Laravel (PHP) dan diletakkan pada server yang sama dengan database. Aplikasi Mobile untuk mahasiswa dibangun diatas cross Total tabel yang dibentuk baik sebagai master data maupun transaksi sejumlah 13, yaitu terdiri dari tabel dosen, tabel dosen_login, tabel dosen_matkul, tabel jadwal_kuliah, tabel mahasiswa, tabel mahasiswa_login, tabel mahasiswa_matkul, tabel mahasiswa_notif, tabel mata_kuliah, tabel presensi, tabel presensi_rekap, tabel ruangan, dan tabel tahun_ajaran.

platform framework FireMonkey (Delphi). Tahap Kemudian pada Gambar 3 ditunjukkan use case diagram terakhir yaitu evaluasi, dilakukan dengan memastikan mahasiswa dan dosen untuk memberikan gambaran fitur sistem terintegrasi dan bekerja dengan baik.

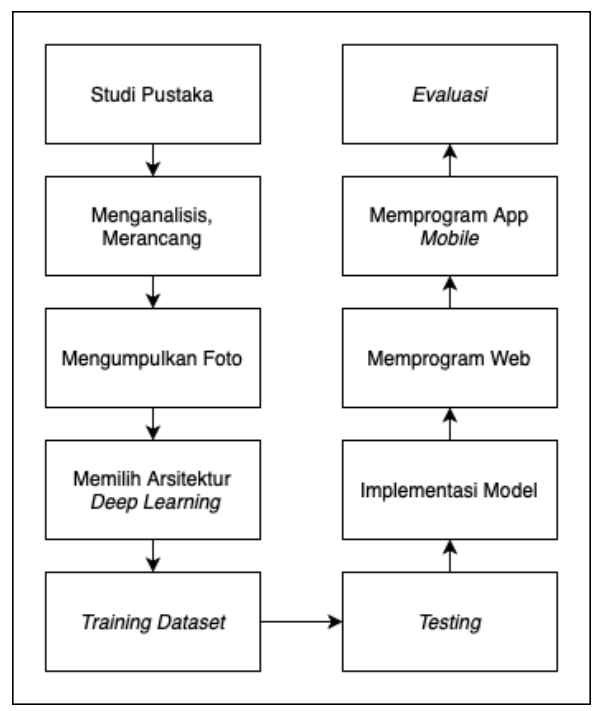

Gambar 1. Diagram Alir Penelitian

\subsection{Analisis Perancangan}

Dalam memenuhi perancangan dan implementasi sistem dibutuhkan perangkat keras dan lunak yang akan digunakan yaitu mini komputer dengan spesifikasi seperti pada Tabel 1 dan untuk training dataset dengan spesifikasi seperti pada Tabel 2.

Tabel 1. Spesifikasi Hardware Mini Komputer

\begin{tabular}{cll}
\hline No & Komponen & Spesifikasi \\
\hline 1 & Processor & Intel Atom Z8350 CPU, quad core \\
2 & Memory & 4GB RAM \\
3 & Storage & SSD 64GB \\
4 & Sistem Operasi & Windows 10 \\
5 & Graphics & Intel HD Graphics 400 \\
\hline
\end{tabular}

Tabel 2. Spesifikasi Hardware untuk Training

\begin{tabular}{cll}
\hline No & Komponen & Spesifikasi \\
\hline 1 & Processor & 2,4 GHz Intel Core i7 \\
2 & Memory & 8 GB 1600 MHz DDR3 \\
3 & Storage & SSD 250GB \\
4 & Sistem Operasi & macOS Mojave \\
5 & Graphics & Intel HD Graphics 4000 \\
& & NVIDIA GeForce GT 650M \\
\hline
\end{tabular}

Perancangan sangat penting dilakukan untuk mempermudah merancang bangun suatu sistem. yang ada. Dosen selaku regulator memiliki fungsionalitas dalam hal memulai kelas dan menyelesaikan kelas. Mahasiswa memiliki fungsionalitas dalam hal konfirmasi kedatangan dan konfirmasi pulang. Baik dosen maupun mahasiswa memiliki fungsionalitas yang sama yaitu login ke sistem.

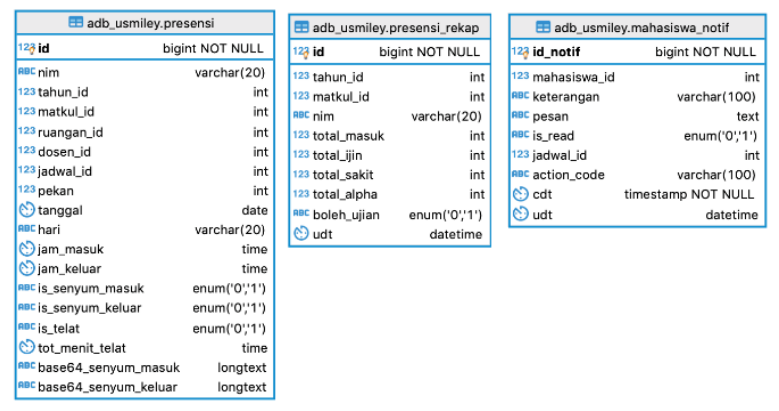

Gambar 2. Tabel Utama Presensi dan Notifikasi

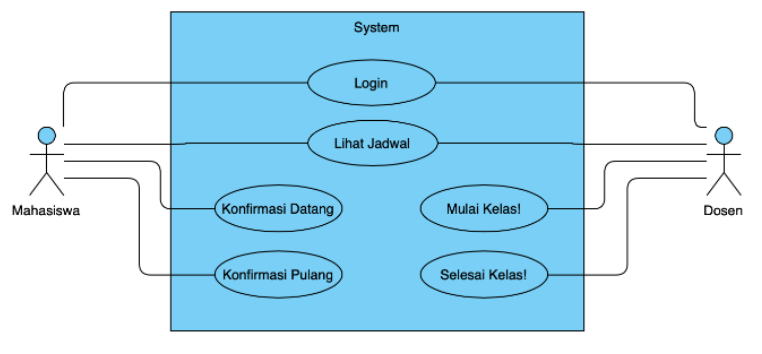

Gambar 3. Use Case Mahasiswa dan Dosen

\subsection{Gambaran Umum Sistem}

Pada Gambar 4 diperlihatkan ilustrasi topologi sistem presensi berbasis deep learning. Sistem ini diterapkan di dalam ruangan yang memiliki sebuah IP CCTV, sebuah mini komputer dan sebuah wireless access point yang terhubung dengan jaringan kampus. Pada mini komputer inilah script Python yang menerapkan model deep learning ditempatkan. Mini komputer terkoneksi dengan IP CCTV dan jaringan kampus. Proses pengiriman data presensi ke database pusat dilakukan melalui Representational State Transfer Application Programming Interface (REST API). Melalui REST API ini aplikasi mobile mahasiswa terhubung untuk melihat data presensi dan konfirmasi kehadiran. 
Konfirmasi hanya dapat dilakukan melalui jaringan kampus.

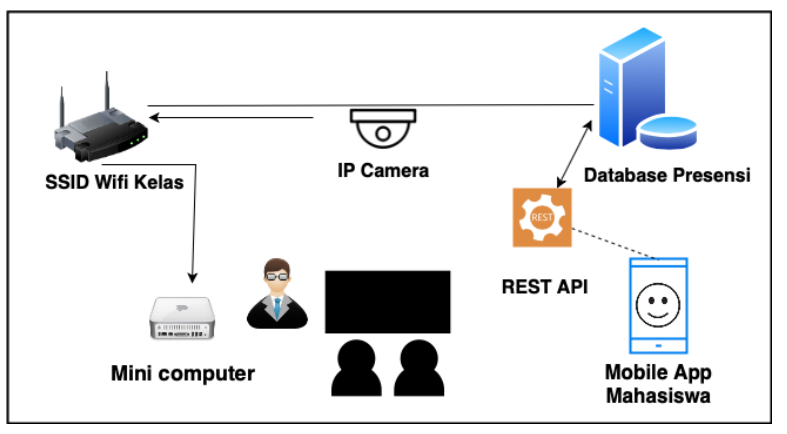

Gambar 4. Topologi Sistem

dimensi, sehingga metode ini cocok untuk pemrosesan dengan input berupa citra [15].

Struktur CNN dapat dilihat memiliki dua tahapan, yakni tahapan ekstraksi fitur (feature learning) dan proses klasifikasi seperti yang tampak pada Gambar 5 [16]. Proses ekstraksi dalam CNN dilakukan pada lapisan konvolusi dan pooling yang menghasilkan feature maps. CNN bekerja secara hierarki, sehingga output pada lapisan konvolusi pertama digunakan sebagai input pada lapisan konvolusi selanjutnya. Pada proses klasifikasi, output dari proses ekstraksi fitur diubah bentuknya menjadi satu dimensi lalu diinputkan ke classifier yang bisa berupa fully-connected layer seperti pada Gambar 5 atau classifier lain [15].

\subsection{Pengumpulan Dataset dan Training}

Dataset yang digunakan pada penelitian ini berupa citra wajah yang diperoleh melalui dua cara. Cara pertama dilakukan dengan mengumpulkan foto mahasiswa. Sedangkan cara kedua dilakukan dengan mengumpulkan video mahasiswa berdurasi sekitar 1-2 menit dengan beragam pose. Video tersebut kemudian diolah dengan cara memotong frame per detik untuk memperoleh sekitar 60-120 foto per video. Sebelum digunakan untuk training set dan testing set, foto-foto tersebut harus dilakukan pra-pemrosesan terlebih dahulu menyesuaikan arsitektur yang dipilih yaitu FaceNet dengan dimensi 160x160 piksel dengan menggunakan script Python yang menerapkan face detection MTCNN [13].

Training dalam Deep Learning adalah proses melatih arsitektur Deep Learning menggunakan dataset dan menghasilkan suatu model pembelajaran. Untuk menghasilkan model tersebut dibutuhkan hardware dengan spesifikasi seperti pada Tabel 2. Selain itu, beberapa library digunakan seperti Tensorflow dan Keras ditunjukkan pada Tabel 3.

\begin{tabular}{cll} 
Tabel 3. & \multicolumn{2}{c}{ Library yang digunakan untuk training } \\
\hline No & Library & Versi \\
\hline 1 & grpcio & 1.32 .0 \\
2 & h5py & 2.10 .0 \\
3 & imageio & 2.9 .0 \\
4 & Keras-Preprocessing & 1.1 .2 \\
5 & numpy & 1.16 .0 \\
6 & opencv-contrib-python & 4.4 .0 .44 \\
7 & Pillow & 7.2 .0 \\
8 & protobuf & 3.13 .0 \\
9 & scikit-learn & 0.23 .2 \\
10 & scipy & 1.2 .2 \\
11 & tensorflow & 1.7 .0 \\
\hline
\end{tabular}

\subsection{Convolutional Neural Network}

Convolutional Neural Network (CNN) adalah salah satu arsitektur jaringan saraf tiruan yang termasuk dalam Deep Learning dan didesain khusus untuk menangani data berbentuk larik. CNN menerapkan operasi konvolusi pada satu atau lebih lapisannya yang DLib merupakan sebuah library machine learning terinspirasi oleh sistem saraf biologis [14]. Pada CNN yang ditulis dalam bahasa pemrograman C++ [20]. setiap neuron dipresentasikan dalam bentuk dua Pada penelitian ini DLib digunakan untuk cropping atau

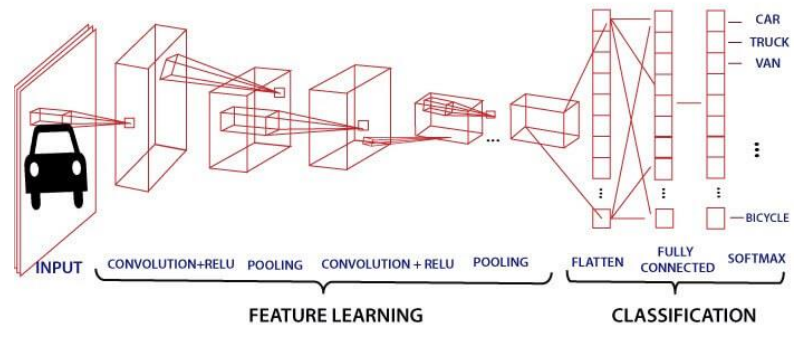

Gambar 5. Ilustrasi Convolutional Neural Network [17]

\subsection{Arsitektur FaceNet}

FaceNet merupakan sistem pengenalan wajah yang dikembangkan oleh peneliti Google. FaceNet mengekstrak fitur wajah menjadi vektor menggunakan arsitektur deep Convolutional Neural Network (deep $\mathrm{CNN}$ ). Vektor nilai atau vector embedding yang dihasilkan dapat memetakan kemiripan wajah yang memiliki kedekatan posisi pada embedding space. Model Deep CNN yang digunakan pada FaceNet bisa berupa ZF-Net atau Inception [18].

Pada penelitian ini kami menggunakan FaceNet pada tahapan feature learning. Hasil dari FaceNet yang berupa vektor sebanyak 128 elemen atau Face embedding diklasifikasi menggunakan SVM. Model SVM mengklasifikasi identitas wajah dari vector embedding tersebut.

\subsection{Library Tambahan}

OpenCV (Open Source Computer Vision Library) adalah salah satu software pustaka yang ditujukan untuk pengolahan citra dinamis secara real-time [19]. OpenCV dapat diterapkan dengan menggunakan bahasa Python untuk keperluan pemrosesan citra digital dari bermacam sumber seperti video, kamera, maupun protokol lain seperti Real Time Streaming Protocol (RTSP). Pada penelitian ini OpenCV digunakan untuk keperluan pengumpulan dataset foto, mengolah frame dari IP

CCTV, dan untuk mendeteksi pola senyuman. 
mengambil bagian wajah dari suatu gambar yang ditangkap oleh CCTV.

\section{Hasil dan Pembahasan}

\subsection{Dataset Citra Wajah}

Pada Gambar 6 ditunjukkan sampel foto salah satu mahasiswa dari total tujuh mahasiswa. Dalam penelitian yang dilakukan, dilakukan proses seleksi dataset yang memiliki variasi wajah yang cukup beragam dan memenuhi jumlah minimal foto sehingga didapatkan sejumlah tujuh mahasiswa. Masing-masing mahasiswa memiliki 100 foto. Dari 100 foto tersebut dibagi menjadi tiga bagian, yaitu 10 foto digunakan sebagai data testing, 75 foto sebagai data training, dan 15 foto untuk data validation.
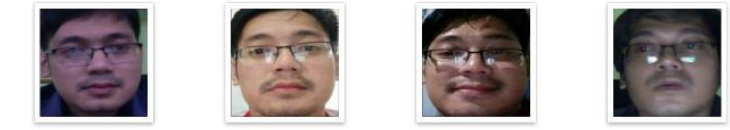

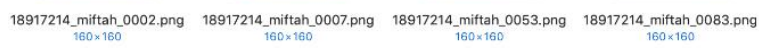

Gambar 6. Contoh Data Foto Mahasiswa

Pada Tabel 4 ditunjukkan jumlah foto satu mahasiswa, dan keseluruhan tujuh mahasiswa untuk mempermudah melihat perhitungan yang dilakukan. Perhitungan ini berdasarkan pembagian yang telah ditentukan sebelumnya menyesuaikan dengan jumlah foto yang dimiliki. Jumlah keseluruhan foto yang digunakan untuk training sebanyak 525 foto, untuk testing sebanyak 70 foto, dan untuk validation sebanyak 105 foto.

\begin{tabular}{|c|c|c|c|}
\hline No & $\begin{array}{l}\text { Nama } \\
\text { pembagian }\end{array}$ & $\begin{array}{c}\text { Jumlah Foto Satu } \\
\text { Mahasiswa }\end{array}$ & $\begin{array}{c}\text { Jumlah Foto Tujuh } \\
\text { Mahasiswa }\end{array}$ \\
\hline 1 & Training & 75 & 525 \\
\hline 2 & Testing & 10 & 70 \\
\hline 3 & Validation & 15 & 105 \\
\hline & Total & 100 & 700 \\
\hline
\end{tabular}

\subsection{Training}

Setelah dataset tersedia dan pembagian data ditentukan, selanjutnya dilakukan proses training. Pada Tabel 4 total foto yang digunakan untuk training sejumlah 525 foto. Sebelum dilakukan training, dilakukan alignment atau mengubah dimensi foto menjadi 160x160 dengan menggunakan script Python.

Selanjutnya dilakukan training dengan menggunakan script Python dengan spesifikasi seperti pada Tabel 2. Dalam prosesnya, untuk pertama kali akan di-load Pretrained model dari FaceNet. Sejumlah foto tersebut menjadi input untuk diekstraksi fitur-fiturnya dan melewati beberapa layer-layer yang ada di arsitektur. Hasil akhir proses training ini akan dihasilkan sebuah model berekstensi pickle sebesar $649 \mathrm{~KB}$.

\subsection{Testing}

Dalam menguji suatu model deep learning perlu dilakukan testing model, dengan menggunakan dataset sendiri selain dari training dan validation. Hasil testing ini berupa nilai akurasi. Akurasi dihitung berdasar berapa banyak model mampu mengklasifikasi dengan benar wajah yang diperoleh. Pada Tabel 4, total foto yang digunakan untuk testing sejumlah 70 foto. Testing ini mendapatkan nilai akurasi sebesar 92,6\%.

Cara lain untuk melakukan testing adalah dengan menggunakan tangkapan layar dari IP CCTV. Sebagai eksperimen disini dilakukan pengambilan sampel sejumlah lima foto dari IP CCTV dengan situasi yang berbeda dan tiap foto minimal terdiri dari dua orang seperti ditunjukkan pada Gambar 7. Dimensi yang digunakan untuk testing adalah 160x160, maka foto tadi perlu dilakukan crop pada area wajah dengan menggunakan library OpenCV dan DLib. Beberapa crop wajah bisa dilihat seperti pada Gambar 8. Setiap image hasil crop selanjutnya dilakukan proses identifikasi. Hasil akurasi pengenalan wajah dari eksperimen ini hanya sebesar $66,7 \%$. Hasil testing live lebih kecil dari hasil testing model dan selisihnya cukup jauh, kondisi seperti ini disebut overfitting. Overfitting adalah suatu keadaan model terlalu mengacu pada data pelatihan yang digunakan. Hasil yang overfitting dapat disebabkan oleh beberapa hal seperti epoch terlalu banyak, dan kurangnya variasi gambar data pelatihan [21].

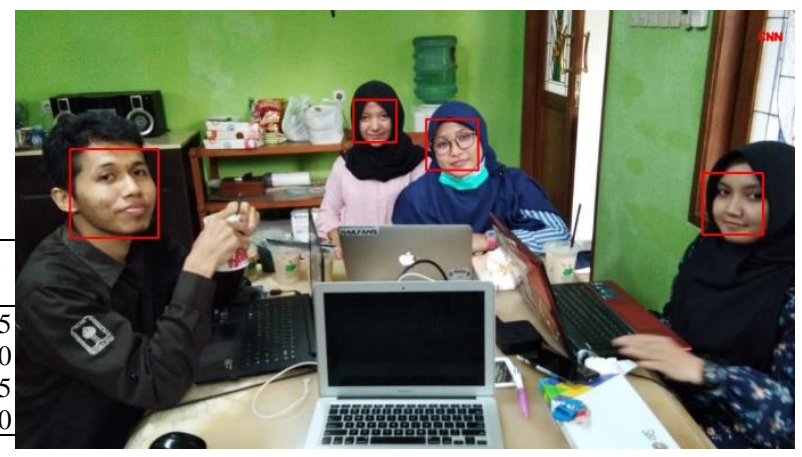

Gambar 7. Tangkapan Layar dari IP CCTV
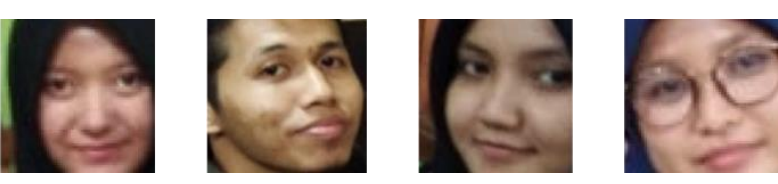

Gambar 8. Face Detection

\subsection{Implementasi Model}

Dalam pengenalan wajah mahasiswa melalui IP CCTV ini, dibuat pipeline script Python yang mengakses CCTV menggunakan OpenCV dengan protocol RTSP. Frame diambil per detik. Tiap frame akan dilakukan pendeteksian wajah dengan konsep face alignment untuk selanjutnya dilakukan face recognition. Tahap face recognition membutuhkan model dari FaceNet dan model yang telah di-training. Gambar 9 menunjukkan bagaimana pipeline Python bekerja dalam mengimplementasikan model FaceNet. 


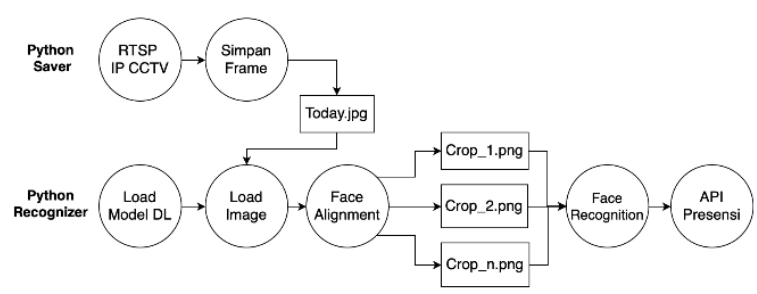

Gambar 9. Implementasi Model di Pipeline Python

Script Python ini berjalan di mini komputer, terdiri dari dua service utama yaitu bagian penyimpanan image dan bagian pengenalan wajah. Blok bagian pertama mengakses IP CCTV melalui protokol RTSP, mendapatkan frame image, lalu disimpan menjadi sebuah file image berekstensi jpg dengan format penamaan today.jpg. Blok bagian kedua berjalan secara berkesinambungan memproses file today.jpg. Proses pertama yaitu load model deep learning terlebih dahulu, lalu load image today.jpg. Image yang di-load akan diproses untuk dideteksi ada berapa wajah. Setiap wajah yang dideteksi selanjutnya di-crop dan disimpan menjadi file image berektensi jpg. Setiap file crop ini diolah oleh model deep learning yang telah diload sebelumnya. Hasil dari identifikasi model adalah pengenalan berupa NIM dari wajah tersebut. NIM ini digunakan sebagai ID untuk presensi melalui Applicaton Programming Interface (API) presensi.

\subsection{Aplikasi Web Dosen}

Pada saat proses kegiatan belajar mengajar, dosen berperan untuk membuka dan menutup kegiatan pembelajaran. Hal tersebut dilakukan melalui aplikasi web yang telah terintegrasi dengan sistem presensi yang ada. Pada aplikasi web ini disediakan fitur untuk melihat jadwal per hari. Dari tiap jadwal tersebut terdapat tombol Mulai dan Selesai. Tombol Mulai untuk menyatakan bahwa kelas telah dimulai dan presensi mulai dicatat seperti pada Gambar 10. Presensi masuk dilakukan secara otomatis di mini komputer yang mengakses IP CCTV. Selanjutnya dari proses apt pengenalan wajah tangkapan CCTV tadi didapat Nomor Induk Mahasiswa (NIM), jika sesuai dengan database mahasiswa yang terdaftar maka data dimasukkan ke tabel presensi. Saat pembelajaran telah selesai, dosen menekan tombol Selesai untuk menyatakan bahwa kelas boleh ditinggalkan. Alur proses bagaimana aplikasi web ini bekerja ditunjukkan pada Gambar 11.

Aplikasi web diakses melalui Uniform Resource Locator (URL), dan mewajibkan login terlebih dahulu menggunakan Nomor Induk Karyawan (NIK) dan kata sandi. Apabila otentifikasi berhasil, menu dapat digunakan, terutama menu Daftar Kelas. Daftar Kelas menampilkan jadwal sesuai tanggal akses. Dosen memilih kelas yang dipilih dan menekan tombol Mulai Kelas untuk memulai perkuliahan. Apabila kelas telah usai, tombol Selesai Kelas ditekan, secara otomatis memberikan trigger berupa notifikasi ke smartphone mahasiswa untuk melakukan konfirmasi.

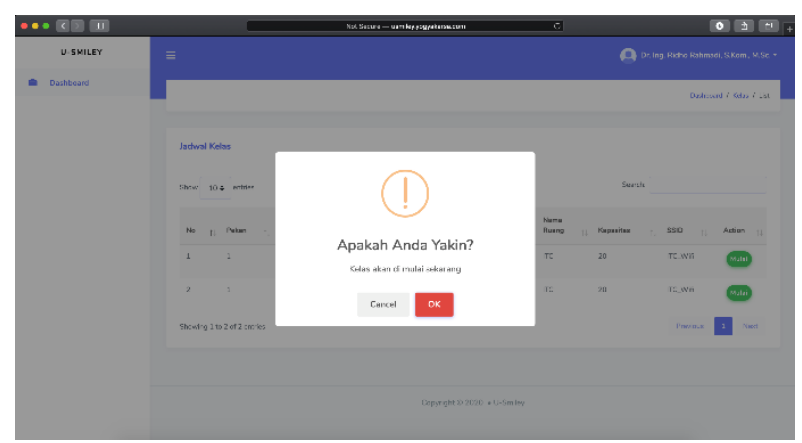

Gambar 10. Konfirmasi Kelas Dimulai oleh Dosen

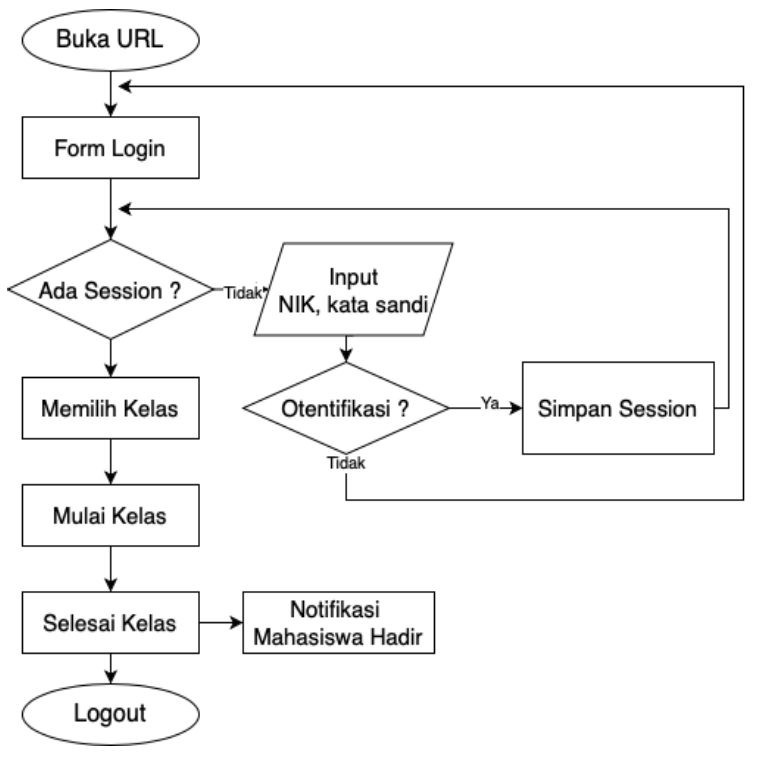

Gambar 11. Flowchart Aplikasi Web

\subsection{Aplikasi Mobile Mahasiswa}

Penggunaan aplikasi mobile bagi mahasiswa turut mendukung jalannya sistem presensi ini. Melalui aplikasi mobile, mahasiswa akan mendapatkan notifikasi berupa pesan telah tercatat masuk di kelas maupun nanti saat kelas sudah selesai. Mahasiswa diwajibkan untuk melakukan konfirmasi dengan melakukan selfie dengan wajah tersenyum untuk presensi masuk dan presensi keluar. Dua senyuman ini dihitung sebagai satu record presensi untuk setiap mahasiswa. Ilustrasi ditunjukkan pada Gambar 12 dan Gambar 13. Sedangkan alur proses bagaimana aplikasi mobile ini bekerja ditunjukkan pada Gambar 14.

Aplikasi mobile mewajibkan login terlebih dahulu menggunakan Nomor Induk Mahasiswa (NIM) dan email. One-Time Password (OTP) dikirim melalui email untuk dicocokkan. Setelah otentifikasi berhasil maka tampilan yang pertama muncul adalah Daftar Jadwal. Ada background service di mobile yang memunculkan notifikasi apbila mahasiswa yang bersangkutan diidentifikasi memasuki kelas, dan dosen menyatakan kelas selesai. Apabila CCTV berhasil mengidentifikasi 
mahasiswa saat hadir di kelas, sebuah ikon lonceng dimunculkan. Mahasiswa melakukan konfirmasi dengan selfie tersenyum. Apabila dosen menyatakan kelas telah selesai, ikon lonceng muncul juga di daftar jadwal yang sesuai. Mahasiswa sekali lagi melakukan konfirmasi dengan selfie tersenyum. Pengenalan pola senyuman ini menggunakan API Python dan library OpenCV yang mengenali senyuman dari selfie image yang dikirimkan.

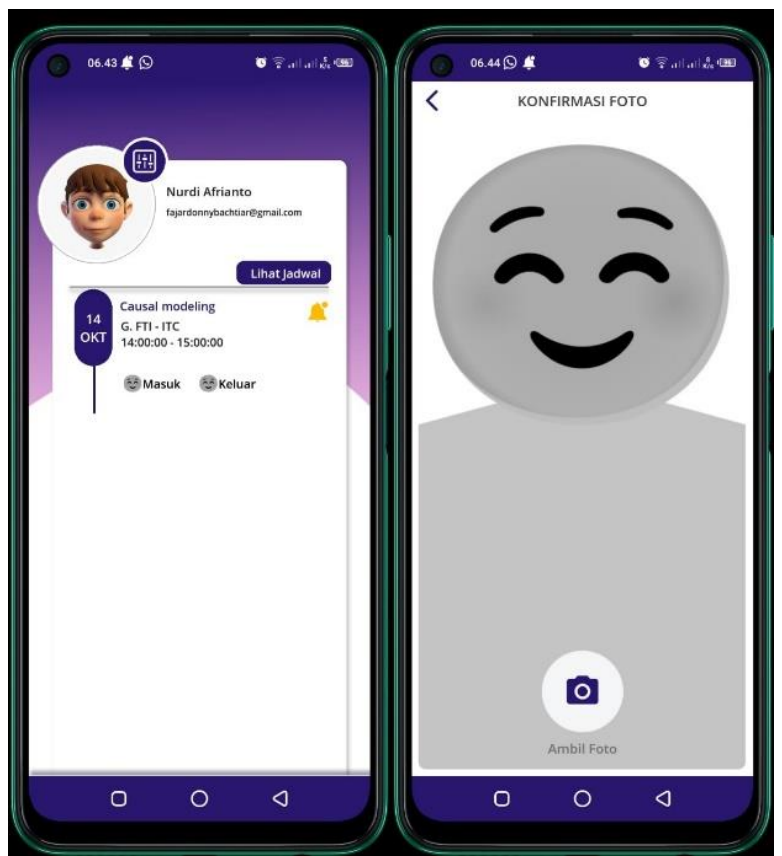

Gambar 12. Notifikasi dan Konfirmasi Presensi di Mobile App

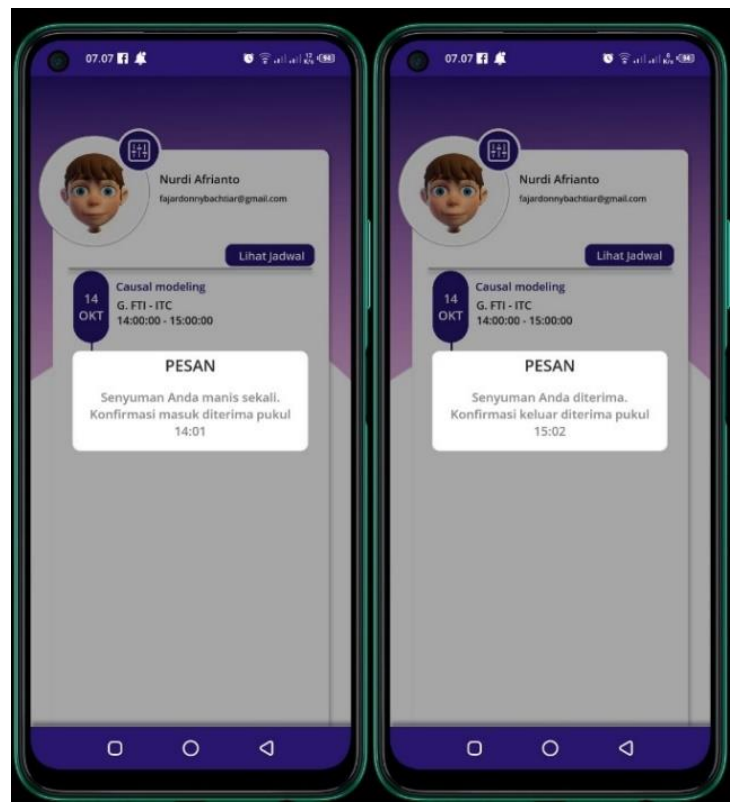

Gambar 13. Pesan Balasan dari Sistem Setelah Konfirmasi di Mobile App

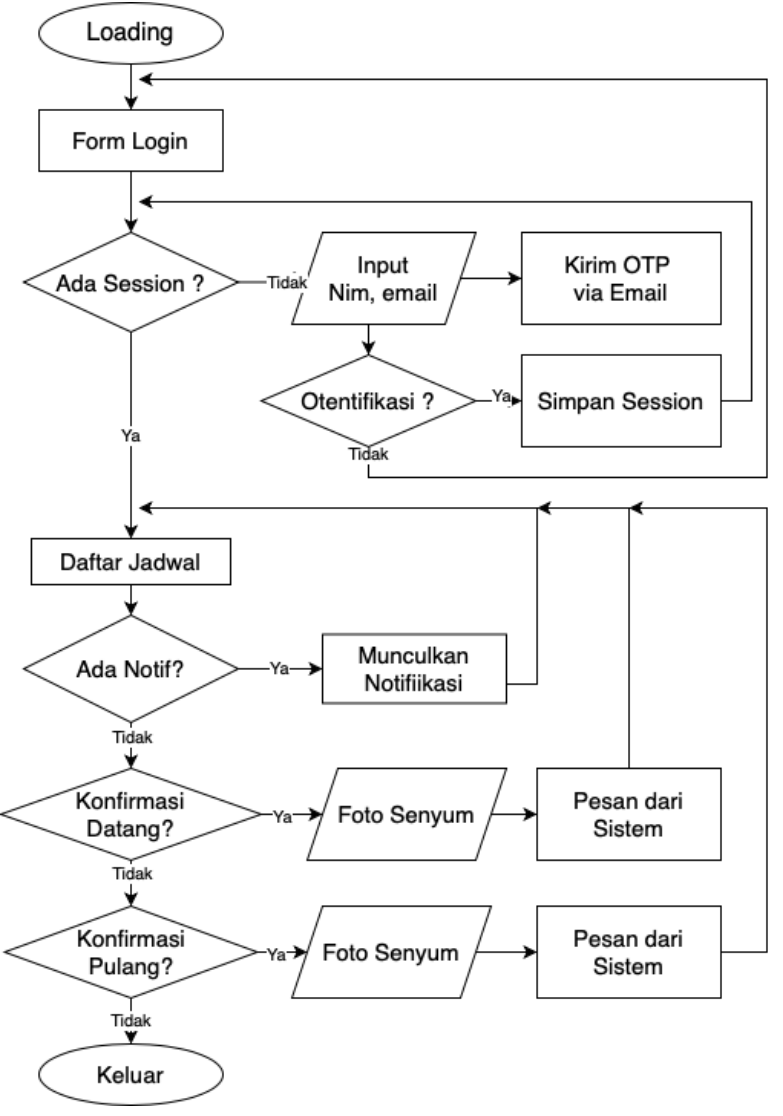

Gambar 14. Flowchart Aplikasi Mobile Mahasiswa

\section{Kesimpulan}

Dari penelitian yang dilakukan didapatkan hasil terbentuknya sistem presensi terintegrasi web, mobile, dan service yang menerapkan arsitektur deep learning berbasis CNN yaitu FaceNet. FaceNet digunakan sebagai feature extractor yang dikombinasikan dengan SVM sebagai classifier. Selain itu, validasi diperkuat dengan kondisi pengecekan lokasi berdasarkan SSID yang dicocokkan database, dan waktu berdasarkan kapan waktu pengidentifikasian wajah di server. Sebagai konfirmasi, mahasiswa juga diwajibkan selfie tersenyum sebagai penguat keabsahan presensi. Sistem terintegrasi ini siap diujicoba secara nyata, tetapi mengingat masih masa pandemi Covid-19 saat ini masih dalam bentuk purwarupa.

Hasil pengujian dari model deep learning dilakukan dengan dua cara yaitu testing secara model dan testing secara live dengan sampel. Hasil akurasi dari testing model sebesar 92,6\% sedangkan untuk testing live akurasi hanya sebesar $66,7 \%$. Nilai testing live lebih kecil dan cukup jauh dari testing model dapat diartikan hasil training model terlalu overfitting, disebabkan kurang beragamnya citra wajah yang dikumpulkan tiap mahasiswa pada penelitian ini. Untuk studi selanjutnya kami menyarankan untuk lebih beragamnya pengumpulan dataset citra wajah tiap mahasiswa sebagai salah satu cara meningkatkan akurasi. 


\section{Ucapan Terimakasih}

Penelitian ini didukung oleh Hibah Penelitian Tesis Magister dari KEMENRISTEKDIKTI dengan Nomor 081/SP2H/AMD/LT/DRPM/2020.

\section{Daftar Rujukan}

[1] A. Fakih, I. K. Raharjana, and B. Zaman, "Pemanfaatan Teknologi Fingerprint Authentication untuk Otomatisasi Presensi Perkuliahan," J. Inf. Syst. Eng. Bus. Intell., vol. 1, no. 2, p. 41, Nov. 2015, doi: 10.20473/jisebi.1.2.41-48.

[2] T. Matsumoto and H. Matsumoto, "Impact of artificial gummy fingers on fingerprint systems," Proc. ..., 2002.

[3] Samirso, "ZKTeco - How to Enter the Device Without Admin Affirming." https://www.instructables.com/id/ZKTeco-How-toEnter-the-Device-Without-Admin-Affir (accessed Aug. 17, 2019).

[4] William and A. P. U. Sembiring, "Implementasi Identifikasi Sidik Jari Pada Sistem Informasi Penjualan," Semin. Nas. Sist. Inf. Indones., vol. 2013, p. 351, 2013.

[5] U. Syafitri, "Efektivitas Penerapan Absensi Finger Print Pada Lembaga Pendidikan Perkebunan Medan," Univ. Medan Area, pp. 23-24, 2018.

[6] C. Suhery and I. Ruslianto, "Identifikasi Wajah Manusia untuk Sistem Monitoring Kehadiran Perkuliahan menggunakan Ekstraksi Fitur Principal Component Analysis (PCA)," J. Edukasi dan Penelit. Inform., vol. 3, no. 1, p. 9, Apr. 2017, doi: 10.26418/jp.v3i1.19792.

[7] Z. Fachmi, M. Sudarma, and L. Jasa, "Sistem Monitoring Kehadiran Perkuliahan Menggunakan Face Detection Dengan Algoritma Viola Jones," Maj. Ilm. Teknol. Elektro, 2019, doi: 10.24843/mite.2019.v18i01.p18.

[8] D. Derisma, "Sistem Pengenalan Wajah Secara Realtime Berbasis Android Menggunakan Metode Eigenface Pada OpenCV," $J$. Komput. Terap., vol. 2, no. 2, pp. 127-136, 2016.

[9] A. Pradana and E. Paulus, "Aplikasi Deteksi Wajah pada Sekumpulan Orang dengan Membandingkan Metode Viola-Jones dan KLT," in SENAPATI 2016, 2016, pp. 230-231.
[10]N. T. Son et al., "Implementing CCTV-based attendance taking support system using deep face recognition: A case study at FPT polytechnic college," Symmetry (Basel)., 2020, doi: 10.3390/sym 12020307 .

[11]M. A. Prasanty and F. Utaminingrum, "Sistem Presensi Mahasiswa Berdasarkan Pengenalan Wajah Menggunakan Metode LBP dan K-Nearest Neighbor Berbasis Mini PC," $J$. Pengemb. Teknol. Inf. dan Ilmu Komput., vol. Vol. 4, no. April 2020, pp. 1168-1171, 2020.

12]G. Q. O. Pratamasunu, O. I. R. Farisi, and M. Jannah, "Pengenalan Wajah Mahasiswa Universitas Nurul Jadid Pada Video Menggunakan Metode Haar Cascade Dan Deep Learning," CoreIT J. Komputasi dan Teknol. Inf., vol. Vol. 1, no. November 2020 , pp. $25-34,2020$.

[13]T. Stat, "Face Recognition Using," vol. 4, no. 2. pp. 2-5, 2003, [Online]. Available: https://github.com/davidsandberg/facenet.

[14]F. Hu, G. S. Xia, J. Hu, and L. Zhang, "Transferring deep convolutional neural networks for the scene classification of highresolution remote sensing imagery," Remote Sens., 2015, doi: $10.3390 / \mathrm{rs} 71114680$

[15]E. Maggiori, Y. Tarabalka, G. Charpiat, and P. Alliez, "Fully convolutional neural networks for remote sensing image classification," 2016, doi: 10.1109/IGARSS.2016.7730322.

[16]J. Yosinki, J. Clune, Y. Bengio, and H. Lipson, "How transferable are features in deep neural networks?," 2014.

[17]JavaTpoint, "Convolutional Neural Network In PyTorch." https://www.javatpoint.com/pytorch-convolutional-neuralnetwork.

[18]F. Schroff, D. Kalenichenko, and J. Philbin, "FaceNet: A unified embedding for face recognition and clustering," 2015, doi: 10.1109/CVPR.2015.7298682.

[19]A. Zein, "Pendeteksian Kantuk Secara Real Time Menggunakan Pustaka OpenCV dan DLIB Python," Sainstech, 2018.

[20]N. Wahyudiana and S. Budi, "Perbandingan Performa Pre-Trained Classifier dLib dan HAAR Cascade (OpenCV) Untuk Mendeteksi Wajah,” J. Strateg., vol. 1, p. 376, 2019.

[21]N. Ramadhani, J. Hendryli, and D. E. Herwindianti, "Pencarian Objek Wisata Bersejarah Di Pulau Jawa Menggunakan Convolutional Neural Network," J. Ilmu Komput. dan Sist. Inf., vol. 7, 2019. 